injection of saline on joint movement is described in one case. The therapeutic application of aspiration of those minor joint injuries must be strictly limited.

We wish to thank Dr. R. A. Robb, Senior Lecturer in Statistics, Mathematics Department, University of Glasgow, for his statistical evaluation of the results. We are grateful to Mrs. M. Morton, Miss C. Bolton, and Miss C. Muir for their help in the preparation of this article.
REFERENCES

Adams, J. C. (1958). Outline of Fractures, Including foint Injuries, 2nd ed., p. 70. Livingstone, Edinburgh.

Brickner, W . Gaston, S. R., Smith, F. M., and Baab, O. D. (1949). Amer. ' 7 . Surg., 78, 631 .

Metcalfe, R. F. (1926). Surg. Gynec. Obstet., 34, 270.

Patrick, J. (1940). Brit. Y. Surg., 27, 108, 737.

Smillie, I. S. (1962). Injuries of the Knee foint, 3rd ed., p. 26. Livingstone, Edinburgh.

Watson-Jones, Sir R. (1955). Fractures and foint Injuries, 4th ed., 2, 509. Livingstone, Edinburgh.

Willems, Ch. (1909). Arch. int. Chir., 4, 5, 423.

\title{
Immunological Aspects of a Population under Prophylaxis Against Malaria
}

\author{
A. VOLLER,* M.SC., PH.D. ; H. WILSON,* M.R.C.S., L.R.C.P., D.C.H., D.T.M.\&H.
}

Brit. med. F., 1964, 2, 551-552

Since the demonstration by Cohen et al. (1961) of the therapeutic effect of malaria-immune gamma-globulin there has been growing interest in the part played by humoral immunity in malaria. Tobie et al. (1962) showed that the course of antibody production could be measured, using the fluorescent antibody technique, in subjects experimentally infected with malaria. Similarly, Voller and Bray (1962) were able to assess the antibody levels in residents of a malaria hyperendemic area of West Africa. These authors noted high malarial antibody titres in cord blood. Their inference that there was a passive transfer of maternal antibody across the placenta was borne out by the demonstration of Edozien et al. (1962) that the gammaglobulin from cord blood had a therapeutic effect on acute malarial infections.

The present preliminary study was undertaken in order to investigate the effects of drug treatment on malarial antibody production in infants and their mothers.

\section{Methods and Results}

The study was carried out at Sukuta, Gambia, West Africa, an area of hyperendemic falciparum malaria. A group of pregnant women were kept under observation at the weekly clinic at Sukuta. From the time of birth of their children or a few months later (see Table) these women and their infants were regularly given once-weekly oral Daraprim (pyrimethamine) (group 1: mothers $25 \mathrm{mg}$. weekly, children $12.5 \mathrm{mg}$. weekly) or placebo (group 2). There were seven mothers and children in each group.

Blood films were examined at regular intervals for malaria parasites. None of the women and only one child, Boobacar Bojang, of Group 1, showed parasitaemia. All the children except Sanna Cham and all the women in group 2 showed parasites at some time during the study period.

In December 1963 finger-prick blood samples were taken into microhaematocrit tubes and the serum was separated and made up to an initial dilution of $1: 25$ (McGregor and Voller, unpublished observations). The indirect fluorescent antibody test was then used to measure the levels of malarial antibody in the sera (Voller and Bray, 1962). Slide antigens used in these tests were thin blood smears taken from children with heavy - Department of Parasitology, London School of Hygiene and Tropical
Medicine and M.R.C. Laboratories, Gambia. infection of Plasmodium falciparum. The slides were stored at $-70^{\circ}$ C. until the day they were used.

The results of the antibody determinations are given in the Table.

\section{Discussion}

In this study malarial antibody was demonstrated in all but one of the unprotected children. In contrast, malarial antibody was not found in any of the infants who had been on antimalarial drug prophylaxis since birth. The average titre of the protected mothers was much lower than that of the unprotected group.

The unprotected children had an average antibody level which was considerably lower than that of their mothers. This is in agreement with the findings of Voller and Bray (1962), who showed that, although children in an endemic area are born with high malarial antibody levels, these drop over the first few months of life. Thus it would appear that the passively transferred maternal gamma-globulin is only short-lived.

This latter point is emphasized by the fact that none of the protected children had detectable antibody, although every

Malarial Antibody Analysis of Protected and Unprotected Mothers and Children in Gambia

\begin{tabular}{|c|c|c|c|c|c|c|}
\hline \multicolumn{4}{|c|}{ Child } & \multicolumn{3}{|c|}{ Mother } \\
\hline Name & $\begin{array}{c}\text { Age } \\
\text { in } \\
\text { Months }\end{array}$ & $\mid \begin{array}{c}\text { Protec- } \\
\text { tion } \\
\text { Period } \\
\text { in } \\
\text { Months }\end{array}$ & $\begin{array}{l}\text { F.A. } \\
\text { Titre }\end{array}$ & Name & $\begin{array}{c}\text { Protec- } \\
\text { tion } \\
\text { Period } \\
\text { in } \\
\text { Months }\end{array}$ & $\begin{array}{l}\text { F.A. } \\
\text { Titre }\end{array}$ \\
\hline
\end{tabular}

\begin{tabular}{l|r|r|r|l|r|r}
\hline \multicolumn{7}{c}{ Group 1: Protected Individuals } \\
Lamin Colley .. & 7 & 7 & $<25$ & Naffe Colley .. & $6 \frac{1}{2}$ & 25 \\
Boobacar Bojang & 10 & 9 & $<25$ & Awa Darameh & 7 & 25 \\
Adams M'Boob & 12 & 9 & $<25$ & Amie Fye & 7 & 400 \\
Ousman Cham... & $4 \frac{1}{2}$ & $4 \frac{1}{2}$ & $<25$ & Yasule Manneh & 4 & 200 \\
Abdouli Sanyang & 9 & 9 & $<25$ & Mariama Dibba & 7 & 100 \\
Bakari Kammara & 12 & 9 & $<25$ & N'Yonko Cham & 7 & 100 \\
Saku Sanko .. & 7 & 7 & $<25$ & Isature Sanyang & 7 & 25 \\
\hline Average & $8 \frac{1}{2}$ & $7 \frac{1}{2}$ & $<25$ & & $6 \frac{1}{2}$ & 125 \\
\hline
\end{tabular}

\begin{tabular}{|c|c|c|c|c|}
\hline \multicolumn{5}{|c|}{ Group 2: Unprotected Individuals } \\
\hline $\begin{array}{l}\text { Momadu Cham. } \\
\text { Lamin Bojang }\end{array}$ & $\begin{array}{r}11 \\
9 \\
11 \\
7 \\
9 \\
10 \\
6\end{array}$ & $\begin{array}{r}200 \\
100 \\
100 \\
50 \\
25 \\
200 \\
<25\end{array}$ & $\begin{array}{l}\text { Manta Jaju .. } \\
\text { Isatou Sanneh } \\
\text { Manyima Cham } \\
\text { Fatou Sanko .. } \\
\text { Manta Bojang } \\
\text { Fatou Touray.. } \\
\text { Awa Cham .. }\end{array}$ & $\begin{array}{l}200 \\
400 \\
400 \\
400 \\
100 \\
800 \\
400\end{array}$ \\
\hline Average & 9 & 100 & & 385 \\
\hline
\end{tabular}


mother in this group did have. In this group, then, all the malarial antibody passively transferred from the mother had disappeared after a few months. The drug prophylaxis was obviously effective in that no antibody was developed in the protected children. It can be concluded that sporozoite challenge at this level does not elicit the production of malarial antibody.

These results would suggest that it might well be possible to gain some idea of the efficiency of eradication schemes by the testing for malarial antibody in sera from children born after such a scheme was instituted. This could be a valuable addition to the examination of thick blood films for parasites.

It is of interest to note that the average malarial antibody titre of the women protected for about seven months was considerably lower than that of the unprotected group. In a study on West Africans resident in Britain, Kuvin and Voller (1963) detected malarial antibody in subjects who had left the endemic area as long as seven years previously. Of course, in these cases the possibility of subpatent infection cannot be ruled out. The same possibility applies to the volunteers experimentally infected with malaria (Collins et al., 1964) in whom antibody was found a year later.

The present results suggest that repeated and frequent infection is necessary to maintain antibody at its highest level.

It must not be thought that the demonstration of malarial antibody implies the existence of an effective functional immunity. The unprotected children in the present study showed evidence of antibody production, but this age-group often carries a heavy load of malaria parasites. A finding of malarial antibody indicates past or present infection with malaria. However, the early antibody production, together with maternal antibody, may account for the relatively mild first malaria infections noted by Bruce-Chwatt (1952) and McGregor (1960).

\section{Summary}

The study describes an investigation, in a hyperendemic falciparum malaria area, into the effects of antimalarial treatment on levels of circulating malaria antibody in a group of women and their children.

Weekly Daraprim (pyrimethamine) was used to suppress malaria in the experimental group. The indirect fluorescent antibody test was used to measure levels of malarial antibody.

None of the protected children had detectable malarial antibody, in contrast to the unprotected group, nearly all of whom had detectable antibody. The average titre of the protected mothers was much lower than that of the unprotected group. It is concluded that repeated and frequent infection is necessary to maintain malarial antibody at a high level.

We thank Dr. I. A. McGregor for providing the excellent facilities for this work and for his valuable advice. The assistance of Keith Williams is gratefully acknowledged. This work was assisted by financial support from the World Health Organization.

\section{REFERENCES}

Bruce-Chwatt, L. J. (1952). Ann. trop. Med. Parasit., 46, 173.

Cohen, S., McGregor, I. A., and Carrington, S. (1961). Nature (Lond.), 192, 733.

Collins, W. E., Jeffery, G. M., and Skinner, J. C. (1964). Amer. f. trop. Med. Hyg., 13, 256

Edozien, J. C., Gilles, H. M., and Udeozo, I. O. K. (1962). Lancet, 2, 951.

Kuvin, S. F., and Voller, A. (1963). Brit. med. F., 2, 477.

McGregor, I. A. (1960). W. Afr. med. f., 9, 260.

Tobie, J. E., Kuvin, S. F., Contacos, P. G., Coatney, G. R., and Evans, C. B. (1962). Amer. F. trop. Med. Hyg., 11, 589.

Voller, A., and Bray, R. S. (1962). Proc. soc. exp. Biol. (N.Y.), 110, 907.

ergotamine tartrate daily, amounting to a total of $504 \mathrm{mg}$. in six

Prolonged Arteriospasm after Overdose of Oral Ergotamine Tartrate in Migraine

\section{Brit. med. F., 1964, 2, 552-553}

There are no reported cases of arteriospastic disease from the oral administration of ergotamine tartrate or its related alkaloids in migraine, but such side-effects have been reported as a result of its use by injection and by suppository (Young and Humphries, 1961 ; Allen, Barker, and Hines, 1962). The following case report is of a woman who had taken an excessive amount of ergotamine tartrate orally $-12 \mathrm{mg}$. daily for six weeks.

\section{CASE REPORT}

A woman aged 40 had had undoubted migraine for 12 years. She was admitted complaining of aching in the right arm for 10 days and painful cold feet for two days. The pain became extremely severe in the right foot and both feet became dead and numb. She had had increasingly severe attacks of migraine for six weeks and had been in bed for a week. She had been taking "migril " tablets, which contain ergotamine tartrate $2 \mathrm{mg}$., cyclizine hydrochloride $50 \mathrm{mg}$., and caffeine (alkaloid) $100 \mathrm{mg}$., for four months. At first she had taken three to four tablets for an attack, but for the previous six weeks she had taken six tablets a day-that is, $12 \mathrm{mg}$. of weeks. In 1959 she had had 24 tablets of ergotamine tartrate prescribed with no ill effects.

On examination the right radial pulse was absent and all the pulses below the femorals were impalpable. Blood-pressure was $130 / 80$ in the left arm. The right foot was white and cold and the toes were blue; the left foot was cold but not discoloured. Apart from a tachycardia of 108 per minute there were no other signs in the cardiovascular system. Chest, abdomen, and C.N.S. were normal. There was never any pyrexia.

Investigations gave the following results: $\mathrm{Hb} 88 \%$; W.B.C. $5,500 /$ c.mm. with a normal differential ; E.S.R. $20 \mathrm{~mm} . / \mathrm{hr}$. (Westergren); blood urea $17 \mathrm{mg} . / 100 \mathrm{ml}$., radiograph of the chest normal ; E.C.G. normal. The E.S.R. fell to $10 \mathrm{~mm}$. $/ \mathrm{hr}$. three days later.

Treatment consisted of bed rest with the extremities exposed to room temperature, and the administration of papaverine hydrochloride $2.5 \%, 1 \mathrm{ml}$. intravenously three-hourly. She was also given anticoagulant agents-heparin, phenindione, and tolazoline $50 \mathrm{mg}$. immediately, then $25 \mathrm{mg}$. four-hourly by mouth.

The next day the right radial pulse was very weak and the blood pressure could not be recorded in this arm. The right foot was still cold, with a patch of cyanosis extending to the outer side of the lower leg. The right femoral pulse was now absent and the left very diminished, with absent pulses below that point. Fortyeight hours after admission there was marked improvement. The severe pain in the right foot had gone, the feet were warm and pink, and all the pulses had returned and were equal, but the bloodpressure in the right arm was $110 / 70$ compared with $125 / 70$ in the left arm. There was no residual gangrene. 